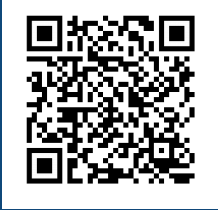

Keywords:

Polyurethane alkyd varnish

Varnish adhesion strength

Varnish layer hardness

Varnish colour measurement

Water-based acrylic varnish

Historic:

Received 01/10/2018

Accepted I |/01/2019

+Correspondence

moncel@kastamonu.edu.tr
Mustafa Öncel ${ }^{\mathrm{la}+}$, Hasan Vurdu' ${ }^{\mathrm{lb}}$, Alperen Kaymakçılc, Osman Emre Özkan ${ }^{\text {ld }}$, Hakan Aydoğan ${ }^{\text {le }}$

\section{COATING PERFORMANCES OF CRIMEAN JUNIPER (Juniperus excelsa M. BIEB.)} WOOD

ÖNCEL, M.; VURDU, H.; KAYMAKÇI, A.; ÖZKAN, O. E.; AYDOĞAN, H. COATING PERFORMANCES OF CRIMEAN JUNIPER (Juniperus excelsa M. BIEB.) WOOD CERNE, v. 25, n. I, p. $36-43,2019$.

\section{HIGHLIGHTS}

Adhesion strength of polyurethane varnish was found to be higher than water-based varnish.

The hardness of the water-based varnish layer was found to be higher than the another one.

The varnished samples showed change towards red and yellow colour as compared to another one.

For Crimean juniper water-based varnish is recommended, when surface hardness is required.

For Crimean juniper polyurethane varnish is recommended, when surface adhesion is desired.

\section{ABSTRACT}

The purpose of this study is to determine the varnish layer hardness and varnish adhesion strength of the varnished Crimean juniper (Juniperus excelsa M. Bieb.) wood growing naturally in the Kastamonu region of Turkey. Test samples were varnished with UV-resistant polyurethane alkyd resin high gloss varnish (PAV) and water-based acrylic resin gloss varnish (WBAV). The varnish adhesion strength test was carried out by using universal testing machine. The varnish layer hardness was measured by using König pendulum hardness tester. Additionally, the colour properties were measured by spectrophotometer equipment that used the L*a*b* colour space. The adhesion strength of the polyurethane varnish and the water-based varnish were determined 2.8I MPa and 2.25 MPa respectively. Surface hardness value for water-based varnish and polyurethane varnish were determined $7 \mathrm{I}$ and 25 oscillation respectively. Detecting the performance of polyurethane and water-based varnish applications for the Crimean juniper wood will provide guidance in which type of varnish will be better for finishing. As a result, in varnish applications of the wood, it is recommended that water-based acrylic varnish should be applied when surface hardness is required. In addition, polyurethane alkyd varnish should be applied when better surface adhesion strength is desired.
' Kastamonu University, Faculty of Forestry, Kastamonu, Turkey - ORCID: 0000-000 I -5964-5 I I 9a, 0000-000 I-9484$2783^{\mathrm{b}}, 0000-0002-8009-7775^{c}, 0000-0003-401$ I-88 I 5 d , 0000-000 I-9482-9888 


\section{INTRODUCTION}

Wood materials have always been one of the most preferred products some sectors such as furniture industry, buildings, fibreboard, particleboard, plywood, paper industry etc., although there are alternatives. However, limited resources of forests and increased consumption depend on developments in technology cause a decrease in the forest resources day by day. To overcome this issue, these materials should have been coated by varnishes and paints in order to ensure longterm use. Finishing applications, especially in furniture and decoration industry were made to prevent the wooden materials from wearing out over time, to provide aesthetic properties to wooden materials and to obtain easily cleanable surfaces (Ulay; Budakçı, 2015). Moreover, wood materials may be exposed to mechanical effects such as abrasion and shock, physical effects such as dust, light, temperature, dirt and oil, chemical effects such as acids, bases, oxidation of air and cleaning products. For coping with all these problems, it is stated that applying surface treatments such as varnish and paint against these external influences are crucial to provide partial durability and protection (Budakçı et al., 2009; Malkoçoğlu et al., 2012). Also, almost all physical and mechanical properties of wood materials decreases when exposed to outdoor conditions without any protection measures (Pelit; Korkmaz, 2017).

Most of the varnishes produced are solvent based in Turkey. However, the importance of water-based paints and varnishes has increased since the Clean Air Agreement, signed in 1970, contains substances that restrict the release of volatile organic compounds into the atmosphere. In addition, the use of binding resins such as polyurethanes in the production of water-based varnish systems has not only led to an increase production of water-based paints and varnishes, increased the use of water-based paints and varnishes as well. These binding resins gain properties such as elasticity, resistance to chemical and mechanical effects to paints and varnishes. In this context, the hardness value observed in the surface layers is indicative of the durability of the product against external influences. A decrease in the hardness of the paint and varnish layers will result in a fall in the strength of these layers to some mechanical effects such as shock, scratch and friction (Budakçı et al., 2009).

One of the factors affecting the durability of surface treatment such as varnish and paint is the cohesion force between the molecules of the surface treatment materials and adhesion force between the wood and surface treatment materials (Sönmez et al.,
2002; Budakçı et al., 2009). But, the adhesion strength is one of the unstable factors used to determine the durability of protective layers among these (Budakçı; Sönmez, 20l0). In addition, Sonmez et al. (2009) states that the adhesion strength in hardwoods is higher than softwoods. There are several methods used to determine the adhesion strength. It has also been found that the most preferred of these are the pull-off test and the cross-cut test (Budakçı; Sönmez, 20l0).

According to place of use of wood products, protective surface applications show changes. For instance, polyurethane, acrylic or water-based varnishes are generally used for varnishing of solid wood parquets. Water-based varnishes are used instead of solvent-based varnishes especially in large halls in order not to cause health problems. Laminated flooring is usually varnished with 5-7 times using by acrylic or polyurethane varnishes. Then, the varnished surface is dried by using UV drying system (Döngel et al., 2008). Hence, determining the performance of polyurethane alkyd varnish (PAV) and water-based acrylic varnish (WBAV) applications for the Crimean juniper wood will provide guidance in detecting which types of varnishes will be better for finishing of juniper wood.

Sönmez et al. (2004), in their study, one and two components water-based varnishes were applied on Scotch pine (Pinus silvestris L.), beech (Fagus orientalis L.), and oak (Qercus petreae L.) wood sample surfaces with brush, sponge roller and spray gun. As a result, they found that the application method was not effective on the hardness and adhesion strength values of the waterbased varnish layers, whereas the spraying method was effective on the glossiness. In a study conducted by Salca et al. (2016), it was shown that black alder wood (Alnus glutinosa Gaertn. L.) samples varnished by using waterbased and UV varnishes by two application methods. As compared to spraying, the application of roller method caused to a higher adhesion strength and glossiness for UV coated samples. On the other hand, water-based coating by using spraying presented a better adhesion than those of UV coating.

In comprehensive study of adhesion strength, Darmawan et al. (2018) employed the crosscut tape method at the determination of the adhesion strength. They found that as the surface roughness of the jabon (Anthocephalus cadamba) and sengon (Paraserianthes falcataria) wood samples varnished with water-based acrylic and oil-based alkyd decreased, the adhesion strength of the both varnished wood samples went down. Similarly, in an investigation into adhesion 
strength, Vitosytè et al. (20I2) found that the ash (Fraxinus excelsior L.) and birch (Betula L.) wood samples coated with 3 different acrylic-polyurethane varnishes presented a better adhesion strength with the increasing of surface roughness. A recent study by Bekhta et al. (2018) showed that adhesion strength values of veneer samples varnished after thermally pressing process exhibited higher values than control samples. Moreover, Altun and Esmer (2017) stated in their research that ash (Fraxinus excelsior L.), Scotch pine (Pinus sylvestris L.) and iroko (Chlorophora excelsa) wood samples were heat treated by using ThermoWood ${ }^{\mathrm{TM}}$ method. Then, they applied various varnishes to the surfaces of the samples and determined not only the effects of surface roughness, but also varnish types on varnish adhesion strength. As a result of their research, it was determined in heat treated samples that the varnish adhesion strength was generally lower. The increase in surface roughness up to the certain limits caused an increase in varnish adhesion strength. The highest adhesion strength was found in the samples coated with polyurethane varnish. They also expressed that the water-based varnish had the lowest adhesion strength.

Budakçı et al. (2009) prepared water-based varnish by adding the boric acid solution in different ratios and they investigated that the impact of that modified varnish on the hardness of varnish layer. They showed that boric acid modification increased the hardness value of the varnish layer. Anwar et al. (2018) investigated mechanical properties of samples coated with nanoclay added water-based varnish. They observed that adding of nanoclay at the percentage 2,4 , and 6 was not significantly effect on the adhesion strength. Also, they stated that the increasing amount of nanoclay percentage of varnish could cause an increase the mechanical properties of water based coated samples up to a certain percentage.

Saygin and Budakçı (2017) aimed in their study that determining the impact of resin and resin cleaning methods on the hardness of water-based varnish layer. Consequently, those cleaning applications had not any effect on layer hardness of water-based varnishes. One study by Özçiftçi et al. (1999) examined wood samples varnished with acrylic, synthetic, polyurethane and acidcatalysed varnishes after than bleaching with sodium hydroxide + hydrogen peroxide, sodium hydroxide + calcium hydroxide + hydrogen peroxide, hypochlorite and hydrochloric acid. They demonstrated the effect of bleaching on the glossiness of varnish layer and adhesion strength of varnish. Consequently, they observed that there was no effect of bleaching process on the glossiness of the varnish layer. Additionally, they found that varnish type and wood species had effect on the glossiness of the varnish layer. Moreover, they showed that the $\mathrm{HCl}$ solution, one of the bleaching chemicals, reduced the adhesion strength of the varnishes.

Palija et al. (2013) investigated that the impact of the staining of spruce wood (Picea abies Karst.) on the adhesion strength of different types of varnishes (nitrocellulose, polyurethane and water based varnishes). They found that water-based varnish had the highest adhesion strength value (4.50 MPa) within the used varnishes for unstained (control) samples, while polyurethane varnish had the highest adhesion strength value $(4.87 \mathrm{MPa})$ within the used varnishes for stained (test) samples. In a study of Ghofrani et al. (2016), wood extractives was removed from alder (Alnus subcordata) and Ironwood (Zelkova carpinifolia) samples. Then these samples were coated with polyurethane alkyd and polyester varnishes. They found that the extractivefree samples exhibited stronger adhesion strength than untreated (control) samples.

In an analysing of colour changes, Söğütlü and Döngel (2009) observed that when cellulosic, synthetic, polyurethane and acid-catalysed varnishes were applied to oak, east beech, chestnut and Scotch pine woods, the most colour changes occurred in synthetic varnished samples. Liu et al. (2012) stated that poplar and scots pine (Pinus sylvestris L.) veneer samples coated with water-based acrylic varnish. They found that the lightness aberration of veneer $\left(\Delta \mathrm{L}^{*}\right)$ and chromatism $\left(\Delta \mathrm{E}^{*} \mathrm{ab}\right)$ significantly reduced. Moreover, detailed examination of colour changes by Yalınkılıç and Sönmez (20I5) showed that only polyurethane and synthetic varnishes caused an increase in the red colour tone in the wood samples obtained from Scots pine, oriental beech and chestnut, which were applied cellulosic, synthetic, polyurethane and acid-catalysed varnishes. In addition, they stated that water-based varnishes caused colour changing effect on mostly in tannin-rich woods. A recent study by Moya et al. (2017) involved that less colour change was observed in 9 kinds of tropical wood samples coated by water-based varnish modified with titanium dioxide nanoparticles after one year of natural weathering process. Detailed examination of high gloss polyurethane and traditional shellac varnishes by Šimůnková et al. (2018) showed that polyurethane varnish was much more durable than shellac varnish. Furthermore, at the beginning of the test, shellac varnish demonstrated better strength to artificial ageing process, while this considerably decreased end of the process. 
Natural colour of wood exists within a range from almost white to black. Furthermore, since most of the diffuse light is absorbed by the varnish layer and then transformed into thermal energy, varnished surface reflects less diffuse light to the observer. Thus, coated wood samples seem darker than uncoated samples. Besides, the moisture content of wood impresses the colour appearance (Meints et al., 2017). Some consumers prefer lighter tones in choosing of wood products, while the others prefer darker tonnes. Hence, it is preferred by the manufacturers to have colour integrity especially in the production of furniture and decoration industries (Fan et al., 20l0; Yalınkılıç and Sönmez, 20I5). However, different colours can be seen in the same wood species. If a colour is desired except that the natural colour of the wood colouring treatment can be apply (Yalınkılıç; Sönmez, 20I5).

Discolouration in the wood depends on both the environmental condition and the chemical composition of the tree species (Fan et al., 2010). Also, It was determined that the colour changes of wood originated electromagnetic radiation causing photochemical reactions in wood material have all the light wavelengths in its structure (Döngel et al., 2008). However, waterbased varnishes could cause darkening of wood because of tannins oxidation (Çakicier et al., 20I I).

In this study, it was aimed to determine the adhesion strength and the hardness of varnish layer of the Crimean juniper (Juniperus excelsa M. Bieb.) wood which grows naturally in the Kastamonu region. Besides, it was focused on the colour measurements of the Crimean juniper wood. For the purpose of this study, the adhesion strength, hardness, and colour measurements tests were conducted. Next, obtained data were analysed statistically by using SPSS 22 . In the last part, the obtained results were interpreted and also some suggestions were given for the future research.

\section{MATERIAL AND METHODS}

\section{Material}

In this study, Crimean juniper (Juniperus excelsa M. Bieb.) wood which is widely used in Turkey was obtained. Finishing was made by using UV-resistant polyurethane alkyd resin with high gloss Caparol ${ }^{\mathrm{Tm}}$ Yachtlack brand varnish (PAV) and water-based acrylic resin Cadence ${ }^{\mathrm{TM}}$ brand varnish (WBAV). Also, Caparol brand Synthetic thinner was used for Caparol ${ }^{\mathrm{TM}}$ Yachtlack brand varnish thinning.

\section{METHODS}

\section{Preparation of test samples}

According to TS 2470 (2005), firstly, logs were cut by quarter cutting method to obtain timbers. Then, the samples were prepared in dimensions of $100 \times 100 \times 15 \mathrm{~mm}$ from these timbers for the use in the measurement of varnish adhesion strength, varnish layer hardness and colour difference. According to TS 247I (2005), the prepared samples were kept at $65 \pm 5 \%$ relative humidity and at $20 \pm 2^{\circ} \mathrm{C}$ for at least I month until the samples reached the air dry.

Varnishing

Test samples were coated according to ASTM-D 3023 (1998), by taking into account the suggestions of the manufacturer for thinner-varnish mixture ratios. Moreover, the samples were coated by using UV-resistant polyurethane alkyd resin with high gloss Caparol ${ }^{\mathrm{TM}}$ Yachtlack brand varnish (PAV) and water-based acrylic resin Cadence $^{\mathrm{TM}}$ brand varnish (WBAV). According to TS EN ISO 325I (20I2), the solid content of WBAV and PAV were determined. After that, the varnishes were applied to the surfaces with a hard bristled brush, with $60 \mathrm{~g} / \mathrm{m}^{2}$ per coat, taking into account the solids content of the varnishes. The percentages of solid content in the varnishes were detected at $46 \%$ in PAV, while at $27 \%$ in WBAV.

In the finishing process, the wood samples were sanded with a rough sandpaper followed by a fine sandpaper and then the dust on the surface of the wood was cleaned. As filler coat varnish, the last coat varnish was used. Then this varnish was applied for the second time for the finishing. For the drying of the varnish layers, after first layer application, samples were waited for 48 hours. The dried filler layer was firstly sanded slightly with 320 grit sandpaper, then the last coat varnish was applied. According to ASTM D-3924 (1996), the coated samples were allowed to dry at a temperature of $20 \pm 2$ ${ }^{\circ} \mathrm{C}$ and a relative humidity of $65 \pm 5 \%$ for three weeks in order to ensure completely drying of the varnish layers.

\section{Adhesion strength of varnish layer}

The test of the varnish adhesion strength was carried out using a 5 ton-capacity Shimadzu brand AG-IC 20/50 KN STD universal testing machine. Test cylinders with a diameter of $20 \mathrm{~mm}$ were adhered to the test specimens with Bison ${ }^{\mathrm{TM}}$ epoxy metal adhesive at normal room temperature $\left(\sim 20^{\circ} \mathrm{C}\right)$. The glued test cylinders were weighed in weight by two kilograms in order to provide the better adhesion during drying. The samples 
were left to dry for 48 hours for drying of the glue on the samples. Before the tests, the samples were conditioned for 24 hours at $50 \pm 3 \%$ relative humidity and $23 \pm 2{ }^{\circ} \mathrm{C}$ temperature according to TS EN ISO 4624 (2016). Then, the bonded test cylinder on the varnish layer was cut from the around of the test cylinder to the surface of the wood sample through a cutter. Finally, in the universal tester, the adhesion of the varnishes were tested in such a way that the speed of the drawing head would be $5 \mathrm{~mm}$ per minute.

The test process and test samples are shown in Figure I and Figure 2 respectively.

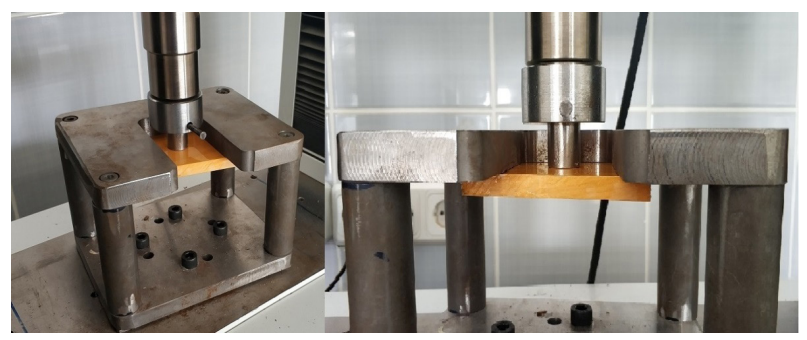

FIGURE I Varnish Adhesion Strength Tests.

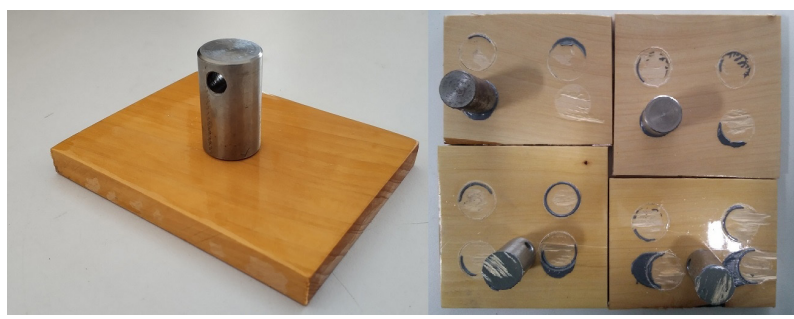

FIGURE 2 Varnish Adhesion Strength Test Samples and Test Cylinders.

Adhesion strength was calculated according to Equation I in $\mathrm{MPa}\left(\mathrm{MPa}=\mathrm{I} \mathrm{N} \cdot \mathrm{mm}^{-2}\right)$, Where: $X$ denotes the adhesion strength $(\mathrm{MPa}), \mathrm{F}$ denotes the rupture force $(N), d$ represents test cylinders with a diameter of $20 \mathrm{~mm}$, and $\pi$ denotes Number of Pi.

$\mathrm{X}=4 \mathrm{~F} \cdot\left(\pi \cdot \mathrm{d}^{2}\right)^{(-1)}$

Hardness of varnish layer

Varnish layer hardness of test samples were measured using a König hardness tester in accordance with ASTM D4366 (2014). The test samples were stored for 24 hours at $23 \pm 2{ }^{\circ} \mathrm{C}$ temperature and 50 $\pm 5 \%$ relative humidity on the basis of TS EN ISO 1513 (2010), before the hardness tests. After this process, the samples were placed on the device and the number of oscillations was observed by damping the pendulum. The test process are shown in Figure 3.

\section{Colour measurement}

Model CM2500d Konica ${ }^{\circledR} \quad$ Minolta spectrophotometer was used for colour measurements. The L*a*b* colour space was used for colour test, in which

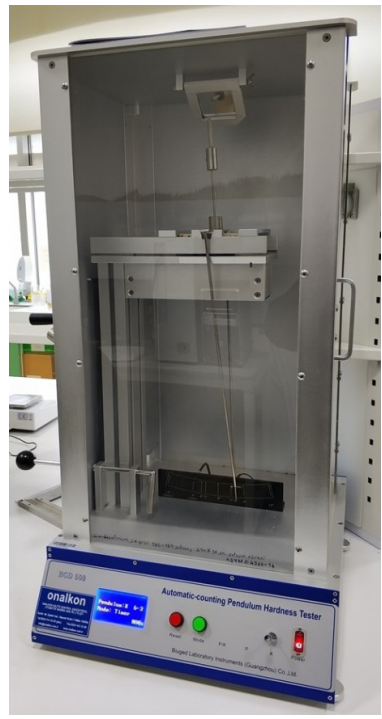

FIGURE 3 Varnish Layer Hardness Tests.

$\mathrm{a}^{*}$ and $\mathrm{b}$ * represented the chromaticity coordinates; $+\mathrm{a}^{*}$ for red $(+60)$, -a* for green $(-60),+b^{*}$ for yellow $(+60)$, and $-b^{*}(-60)$ for blue $L^{*}$ and represented the lightness in the range from black (0) to white (100), (Özkan, Temiz and Vurdu, 2017). For each test samples, four measurement points were marked. Specimens colour coordinates $L^{*}, a^{*}$, and $b^{*}$ values were determined both before and after varnishing. These values were used to calculate the colour change value $\left(\Delta \mathrm{E}^{*}\right)$ among the varnished samples using two different varnishes according to the ASTM D-2244 (2015) standard. Colour measurement test equipment are shown in Figure 4.

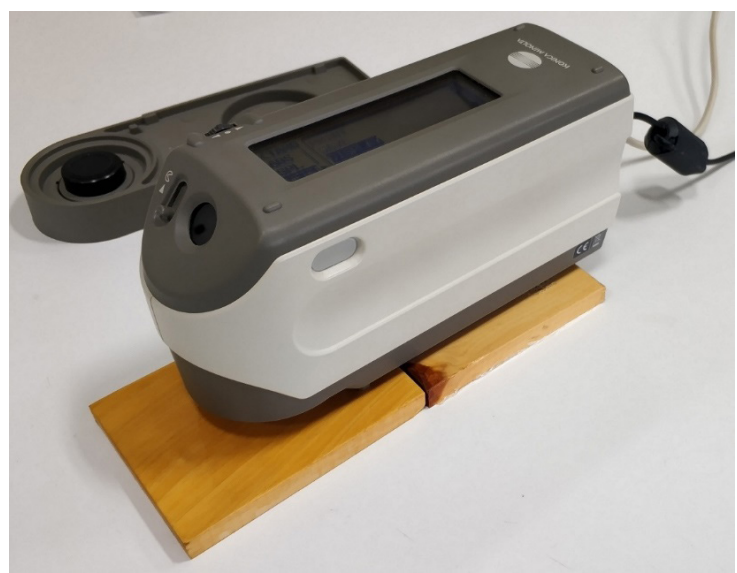

FIGURE 4 Colour Measurement Test Samples and Test Equipment.

The colour change value $\left(\Delta \mathrm{E}^{*}\right)$ among the test samples were calculated by using Equation2, where: $\Delta \mathrm{E}$; Total colour change value, $\Delta \mathrm{L}$; Total colour change value of black (0) to white ( 100$), \Delta \mathrm{a}$; Total colour change value of red $(+60)$ to green $(-60), \Delta \mathrm{b}$; Total colour change value of yellow $(+60)$ to blue $(-60)$.

$$
\Delta \mathrm{E}^{*}=\sqrt{\Delta L^{* 2}+\Delta a^{* 2}+\Delta b^{* 2}}
$$




\section{Statistical analysis}

The obtained data were statistically evaluated by using the SPSS 22 program. The analysis results were given in the part of results and discussion.

\section{RESULTS AND DISCUSSION}

The varnish adhesion strength of samples were given in Table I.

TABLE I Varnish Adhesion Strength Values.

\begin{tabular}{ccccccc}
\hline Samples Type & $\begin{array}{c}\text { Avg. } \\
(\mathrm{MPA})\end{array}$ & $\begin{array}{c}\text { Min. } \\
(\mathrm{MPa})\end{array}$ & $\begin{array}{c}\text { Max. } \\
(\mathrm{MPa})\end{array}$ & S & COV & Sig. \\
\hline WBAV & 2.25 & 1.77 & 2.62 & 0.32 & 14.09 & .000 \\
PAV & 2.81 & 2.38 & 3.28 & 0.38 & 13.63 & .000 \\
\hline
\end{tabular}

Avg.: Average, S: Standard deviation, COV: Coefficient of variation, Sig.: Significance level $\leq 0.05$, WBAV: Water-based acrylic varnish PAV: Polyurethane alkyd varnish.

Table I shows that the comparison and statistical analysis of adhesion strength of samples coated with WBAV and samples coated with PAV. According to the results, in terms of adhesion strength, samples coated with WBAV was found to be higher than samples coated with PAV as $2.25 \mathrm{MPa}$ and $2.8 \mathrm{I} \mathrm{MPa}$, respectively. Additionally, determining the effects of coating types on adhesion strength, $T$ test was performed. According to the $T$ test result, it was found that coating types were statistically significant on adhesion strength $(\alpha<0.05)$. In a study of Budakçı and Sönmez (2010), it was shown that cellulosic, polyurethane, acrylic and water-based varnishes were applied to the scots pine (Pinus sylvestris L.), fir (Abies bornmülleriana Mattf), oriental beech (Fagus orientalis L.) and oak (Quercus petraea L.) wood sample surfaces. They found that the interaction between varnish types and wood species on the surface adhesion strength was significant. Moreover, by supporting our test results, they demonstrated that the highest adhesion strength was obtained from polyurethane and acrylic varnishes.

The varnish layer hardness values were given in Table 2 .

TABLE 2 Varnish Surface Hardness Measurement (Count of König Pendulum Oscillation).

\begin{tabular}{ccccccc}
\hline $\begin{array}{c}\text { Samples } \\
\text { Type }\end{array}$ & $\begin{array}{c}\text { Avg. } \\
\text { (Oscillation) }\end{array}$ & $\begin{array}{c}\text { Min. } \\
\text { Oscillation) }\end{array}$ & $\begin{array}{c}\text { Max. } \\
\text { (Oscillation) }\end{array}$ & S & COV & Sig. \\
\hline WBAV & 71 & 65 & 77 & 3.78 & 5.34 & .000 \\
\hline PAV & 25 & 21 & 29 & 2.42 & 9.74 & .000 \\
\hline
\end{tabular}

Avg.: Average, S: Standard deviation, COV: Coefficient of variation, Sig.: Significance level $\leq 0.05$ WBAV: Water-based acrylic varnish PAV: Polyurethane alkyd varnish.

Overall, Table 3.2 shows that the surface hardness and statistical analysis results of test samples. According to the results, samples coated with WBAV was found to higher than samples coated with PAV in terms of surface hardness as $7 \mathrm{I}$ oscillation and 25 oscillation, respectively. It was reported that differences between tree species had no effect on the hardness of varnish layers, while type of varnish had effect on the hardness of varnish layers (Kaygın and Akgün, 2008). Türkoğlu et al. (20I5) in the study, varnish layer hardness value of Scots pine wood samples coated with polyurethane varnish was found to be 23.4 oscillation. These results support our results from this study.

The colour change values between the varnished samples were given in Table 3 .

TABLE 3 The Colour Change Value.

\begin{tabular}{ccccc}
\hline $\begin{array}{c}\text { Samples } \\
\text { Type }\end{array}$ & $\begin{array}{c}\text { Average L* } \\
\text { Value } \\
\text { (Black-White) }\end{array}$ & $\begin{array}{c}\text { Average } \\
\text { a* Value } \\
\text { (Red-Green) }\end{array}$ & $\begin{array}{c}\text { Average } \\
\text { b* Value }^{*} \\
\text { (Yellow- } \\
\text { Blue) }\end{array}$ & $\begin{array}{c}\text { Colour } \\
\text { difference } \\
(\Delta \mathrm{E})\end{array}$ \\
$\begin{array}{c}\text { of between } \\
\text { unvarnished } \\
\text { and } \\
\text { varnished } \\
\text { samples }\end{array}$ \\
\hline WBAV & 73.97 & 8.18 & 26.86 & 8.90 \\
PAV & 71.44 & 10.14 & 35.33 & 16.84 \\
\hline $\begin{array}{c}\text { Control } \\
\text { (Unarnished) }\end{array}$ & 81.18 & 5.43 & 22.42 & \\
\hline
\end{tabular}

Avg.: Average, S: Standard deviation, COV: Coefficient of variation WBAV: Water-based acrylic varnish PAV: Polyurethane alkyd varnish.

As it was shown on Table 3.3 that total colour change of between unvarnished (control) samples and samples coated with WBAV (test samples) was determined to be 8.90 unit. In addition, the total colour change of between control samples and test samples coated with PAV was determined to be 16.84 unit. The $L^{*}$ value of the test samples showed a slight change towards the black colour as compared to the control samples. Moreover, as compared to the control samples, the $\mathrm{a}^{*}$ and $b^{*}$ values of the test samples showed a slight change towards the red and yellow colour tone, respectively. Besides, in terms of changing towards the yellow colour, especially samples coated with PAV were much greater than samples coated with WBAV. Özçifçi and Atar (2002) studied cellulosic, synthetic, polyurethane and acid-catalysed varnishes applied to Scotch pine, oriental beech and chestnut wood and then they examined colour changes. According to their results, polyurethane varnish increased both yellow and red colour tone. Thus, it was clearly seen that their results supported our results. Specifically, when looking at the varnish types that caused colour change, the $L^{*}$ value of the samples coated with PAV showed a slight change towards the black colour as compared to the samples coated with WBAV. Furthermore, as compared to the samples coated 
with WBAV, the $a^{*}$ and $b^{*}$ values of the samples coated with PAV showed a slight change towards the red and yellow colour, respectively.

\section{CONCLUSIONS}

This paper argued that determining the varnish layer hardness and varnish adhesion strength of the varnished Crimean juniper (Juniperus excelsa M. Bieb.) wood growing naturally in the Kastamonu region of Turkey. Another aim of this study was to investigate the effects of varnish types on the colour change of coated wood samples.

The results of this research showed that the adhesion strength of samples coated with PAV was found to be higher than samples coated with WBAV. Moreover, in terms of surface hardness value, samples coated with WBAV were found to be higher than samples coated with PAV. Hence, this research supports that when surface hardness is required in the varnishing of the Crimean juniper wood, it is recommended that WBAV based should be used. When better surface adhesion is desired, PAV should be used.

For future research, the impact of artificial weathering or natural weathering applications on the adhesion strength, surface hardness value and colour change of coated samples can be studied. Additionally, after the coating of Crimean juniper wood by using wood dyes, the impact of artificial weathering or natural weathering applications on the adhesion strength, surface hardness value and colour change can be studied.

\section{ACKNOWLEDGEMENT}

This paper was presented in IFES 2017 - The International Forestry and Environment Symposium on "Climate Change and Tree Migration" in Trabzon which was held on November 7th to 10th, 2017.

\section{REFERENCES}

AKGÜN, E. Ahşap yüzeylerde kullanılan nanoteknolojik verniklerin dayanım özelliklerinin diğer vernik sistemleriyle karşılaştııılması. 2008. Yüksek Lisans Tezi. Zonguldak Karaelmas Üniversitesi Fen Bilimleri Enstitüsü, Bartın.

ALTUN, S., ESMER, M. Isıl işlemin bazı ağaç malzemelerde yüzey pürüzlülüğü ve vernik yapışma direncine etkisi, Politeknik Dergisi, v.20, n. I, sayfa: 23।-239, 2017.

ANWAR, U. M. K.; ALIA, S. Y.; TUMIRAH, K.; HAMDAN, H.; \& PARIDAH, M. T. Properties of water-borne coating incorporate with nanoclay. In IOP Conference Series: Materials Science and Engineering, v. 368, n.. I, p. 0I2026). IOP Publishing, 2018.
ASTM D2244-15a. Standard practice for calculation of color tolerances and color differences from instrumentally measured color coordinates. 2015. ASTM International, West Conshohocken, PA.

ASTM D4366. Standard test methods for hardness of organic coatings by pendulum damping tests. 2014 . ASTM International, West Conshohocken, PA.

ASTM-D 3023-98. Standard practice for determination of resistance of factory-applied coatings on wood products to stains and reagents. 20II. ASTM International, West Conshohocken, PA.

BEKHTA, P.; KRYSTOFIAK, T.; PROSZYK, S.; \& LIS, B. Adhesion strength of thermally compressed and varnished wood (TCW) substrate. Progress in Organic Coatings, v. $125,331-338,2018$.

BUDAKÇI, M.; \& SÖNMEZ, A. Bazı ahşap verniklerin farklı ağaç malzeme yüzeylerindeki yapışma direncinin belirlenmesi. Gazi Üniversitesi Mühendislik-Mimarlık Fakültesi Dergisi, v.25, n. I, 2010.

BUDAKÇI, M.; UYSAL, B.; ESEN, R.; Borik asit modifikasyonunun su bazlı verniğin sertlik değerine etkisi. 5 . Uluslararası İleri Teknolojiler Sempozyumu (IATS'09), I3-I 5 Mayıs 2009, Karabük, Türkiye, 2009.

ÇAKICIER, N.; KORKUT, S.; \& GÜLER, F. D. Effects of heating treatment on some of the physical properties of varnish layers applied on various wood species. African Journal of Biotechnology, v. I0, n.9, p. I578-I585, 20II.

DARMAWAN, W.; NANDIKA, D.; NOVIYANTI, E.; ALIPRAJA, I.; LUMONGGA, D.; GARDNER, D.; \& GÉRARDIN, P. Wettability and bonding quality of exterior coatings on jabon and sengon wood surfaces. Journal of Coatings Technology and Research, v. I5, n. I, 95-104, 2018.

DÖNGEL, N.; KÜRELI, İ.; \& SÖĞÜTLÜ, C. Kuru sıcaklığın ahşap ve ahşap esaslı döşeme kaplama malzemelerinde parlaklık ve renk değişimine etkisi. Politeknik Dergisi, v. I I, n.3, 2008.

FAN, Y., GAO, J., \& CHEN, Y. Colour responses of black locust (Robinia pseudoacacia L.) to solvent extraction and heat treatment. Wood science and Technology, v.44, n.4, $667-678,2010$

GHOFRANI, M.; MIRKHANDOUZI, F. Z.; \& ASHORI, A. Effects of extractives removal on the performance of clear varnish coatings on boards. Journal of Composite Materials, v.50, n.21, p.3019-3024, 2016.

LIU, Y.; GAO, J. M.; FU, Z.; ZHANG, Y. C.; \& GUO, H. W. The inhibition effects of wood light induced discoloration coating with water-based acrylic varnish. 2012. In Applied Mechanics and Materials (v. 184, pp. I323-1327). Trans Tech Publications.

MALKOÇOĞLU, A.; ÖZDEMIR, T.; TIRYAKI, S. Vernikler renklendiriciler ve boyalar: Hangisini seçmeli. Mobilya Dekorasyon Dergisi, 2012. 
MEINTS, T.; TEISCHINGER, A.; STINGL, R.; \& HANSMANN C. Wood colour of central european wood species: CIELAB characterisation and colour intensification. European Journal of Wood and Wood Products, v.75, n.(4), 499$509,2017$.

MOYA, R.; RODRÍGUEZ-ZÚÑIGA, A.; VEGA-BAUDRIT, J.; \& PUENTE-URBINA, A. Effects of adding $\mathrm{TiO}_{2}$ nanoparticles to a water-based varnish for wood applied to nine tropical woods of Costa Rica exposed to natural and accelerated weathering. Journal of Coatings Technology and Research, v.|4, n.I, p.|4|-I52, 2017.

KAYGIN, B.; AKGUN, E. Comparison of conventional varnishes with Nanolacke UV varnish with respect to hardness and adhesion durability. International Journal of Molecular Sciences, v.9, n.4, 476-485, 2008.

ÖNCEL M., Boylu ardıç (Juniperus excelsa M. Bieb.) odununun bazı fiziksel, mekaniksel ve kimyasal özellikleri. 2016. Kastamonu Üniversitesi Fen Bilimleri Enstitüsü, Orman Endüstri Mühendisliği Anabilim dalı Yüksek Lisans Tezi.

ÖZÇIFÇI, A.; \& ATAR, M. Bazı kimyasal maddelerin karaağaç (Ulmus campestris Spach) odununun renk tonuna etkileri. Teknoloji Dergisi, Yıl 5, Sayı v. I-2, p.2 I-28, 2002.

ÖZÇIFÇI, A.; ATAR, M.; \& UYSAL, B. Ağaç malzemede renk açmada kullanılan kimyasalların yüzey parlaklığına ve verniklerin yapışma mukavemetine olan etkileri, TÜBITAK. Agriculture and Forestry, v.23, n.3, p.763-770, 1999.

ÖZKAN, O. E.; TEMIZ, A.; \& VURDU, H. Effects of heat treatment on Turkish fir wood properties. Wood Research, v. 62, n.5, p.783-794, 2017.

PALIJA, T.; VUČKOVIĆ, A.; JEVTIĆ, P.; \& JAIĆ, M. The impact of wood staining on the adhesion of certain types of coating. In Wood is good-user oriented material, technology and design. Faculty of Forestry, University of Zagreb. Proceedings of the 24th International Scientific Conference, Zagreb, Croatia, pp. III-II8, I8th October 2013.

PELIT, H.; \& KORKMAZ, M. Kayın (Fagus orientalis lipsky) odununun yüzey özelliklerine nano-grafen katkılı su bazlı verniklerin etkisi. Politeknik Dergisi, 2017.

SALCA, E. A.; KRYSTOFIAK, T.; LIS, B.; MAZELA, B.; \& PROSZYK, S. Some coating properties of black alder wood as a function of varnish type and application method. BioResources, v.II, n.3, p.7580-7594, 2016.

SAYGIN, E.; \& BUDAKÇI, M. Reçine temizleme işleminin su bazlı verniklerin sertlik değerine etkisi. Düzce Üniversitesi Bilim ve Teknoloji Dergisi, v.5, p.169- 183, 2017.

ŠIMŮNKOVÁ, K.; PÁNEK, M.; \& ZEIDLER, A. Comparison of selected properties of shellac varnish for restoration and polyurethane varnish for reconstruction of historical artefacts. Coatings, v.8, n.4, p. I 19, 2018.
SÖĞÜTLÜ, C.; \& DÖNGEL, N. Emprenye işleminin ağaç malzeme yüzey pürüzlülüğü ve renk değişimine etkisi. Politeknik Dergisi, v. I2, n.3, 2009.

SÖNMEZ, A.; ATAR, M.; BUDAKÇI, M. Karaağaç (Ulmus campestris Spach.) odununda renk açma işleminin vernik katmanının yapışma direncine etkisi. Teknoloji, Yıl 5, Sayı v. I-2, p.35-42, 2002.

SÖNMEZ, A.; BUDAKCI, M.; \& BAYRAM, M. Effect of wood moisture content on adhesion of varnish coatings. Scientific Research and Essays, v.4, n. I2, p. I432-1437, 2009.

SÖNMEZ, A.; BUDAKÇI, M.; \& YAKIN, M. Ağaç malzemede su çözücülü vernik uygulamalarının sertlik, parlaklık ve yüzeye yapışma direncine etkileri. Politeknik Dergisi, v.7, n.3, 2004.

TURKOGLU, T.; BAYSAL, E.; KURELI, I.; TOKER, H.; ERGUN, M. E. The effects of natural weathering on hardness and gloss of impregnated and varnished scots pine and oriental beech wood. Wood research, v.60, n.5, p.833-844, 2015.

TS EN ISO I5I3. Paints and varnishes - Examination and preparation of test samples. 20I0. Turkish Standart Institute, Ankara, Turkey.

TS EN ISO 325I. Paints, varnishes and plastics Determination of nonvolatile matter content. 2012. Turkish Standart Institute, Ankara, Turkey.

TS EN ISO 4624. Paints and varnishes - Pull-off test for adhesion. 2006. Turkish Standart Institute, Ankara, Turkey.

TS 2470 Wood - Sampling methods and general requirements for physical and mechanical tests. 2005, Turkish Standart Institute, Ankara, Turkey.

TS 247I Wood - Determination of moisture content for physical and mechanical tests. 2005, Turkish Standart Institute, Ankara, Turkey.

ULAY, G.; BUDAKÇI, M. Ahşap yüzeylerde kullanılan su bazlı vernikler ile ilgili Türkiye'de yapılan çalışmalar. Düzce Üniversitesi Bilim ve Teknoloji Dergisi, v.3, n.2, 2015.

VITOSYTĖ, J.; UKVALBERGIENĖ, K.; \& KETURAKIS, G. The effects of surface roughness on adhesion strength of coated ash (Fraxinus excelsior L.) and birch (Betula L.) wood. Materials Science, v. 18, n.4, p. 347-35I, 2012.

YALCIN, M.; PELIT, H.; AKCAY, C.; \& ÇAKICIER, N. Surface properties of tannin $\square$ impregnated and varnished beech wood after exposure to accelerated weathering. Coloration Technology, v. I33, n.4, p.334-340, 2017.

YALINKILIÇ, A. C.; \& SÖNMEZ, A. Effects of water-soluble varnishes on red colour tone in wood material coloured with water-soluble wood stains. Turkish Journal of Forestry, v.16, n.2, p.I52-I58, 2015. 